\title{
直接基礎，杭基礎とパイルド・ラフト基礎の動的相互作用特性 \\ DYNAMIC SOIL STRUCTURE INTERACTION OF SPREAD FOUNDATION, PILE FOUNDATION AND PILED RAFT FOUNDATION
}

\author{
文 学 章*1, 福和 伸夫*2 \\ Xuezhang WEN and Nobuo FUKUWA
}

\begin{abstract}
This paper deals with soil-structure interaction of pile foundation, piled-raft foundation and embedded foundation on pile group. The impedances and foundation input motions are analyzed by the thin layered element method and flexible volume substructure method. The comparison among piled-raft foundation, pile foundation and raft foundation and the comparison among embedded foundation on pile group, piled foundation and embedded foundation are made. Also, the effects of the joint at pile head, the extension at pile tip, the size of raft of piled-raft foundation and the contact condition between soil and the bottom of mat on pile group are discussed. The bending moments in piles subjected to harmonic loads and S-wave input motion are also examined.
\end{abstract}

Keywords: Soil-Structure Interaction, Impedance, Foundation Input Motion, Spread Foundation, Pile Foundation, Piled Raft Foundation, Embedment

構造物と地盤との動的相互作用、インピーダンス、基礎入力動、直接基礎、杭基礎、パイルド・ラフト基礎、根入れ

1 はじめに

耐震基淮の性能規定化と共に導入された限界耐力計算法は、荷重 の動的効果を積極的に取り入れ、表層地盤の增幅や構造物との動的 相互作用効果を導入した点で、従来に比べて大きく進歩した。ただ し、現段階で地盤と構造物との動的相互作用効果を厳密に取り扱う ことは難しく、簡易な地盤ばねの形でモデル化されている。しかし、 基礎形式は、地表面基礎、根入れ基礎、杭基䃈、パイルド・ラフト 基礶、根入れを有する杭基礎など様々な種類があり、それらの動的 相互作用特性の相違を適切に評価して取り入れる必要がある。また、 杭基礎およびパイルド・ラフト基礎の場合、様々な要因（例えば、 杭頭の接合条件、杭の掋底、ラフトの拡大部分、基礎底面の接触条 件など）の影響が考えられる。実際の基礎一地盤系を簡略なモデル で置き換える際には、それらの影響度合いを勘案して結果を吟味す る必要がある。

単独基礎の動的相互作用特性についての研究は、吉田による直接 基礎のインピーダンスと基礎入力動に関する系統的な研究 ${ }^{1)}$ 、杭基 礎に関する群杭効果と杭の地震応答に関する長谷川の研究 ${ }^{2,3)}$ 、パイ ルド・ラフト基礶を対象とした中井らの研究 4)、根入れを有する杭 基礎に関する喜多村の研究 らなどがある。また、異なる基礎形式の 比較については、杭基礎と地表面基礎を比較した飯場の研究 の、根 入れを有する杭基礎を根入れ基礎や杭基礎と比較した高野らの研究 7などがある。筆者らも直接基礎を対象に、隣接建物の存在 ${ }^{8)}$ 、基礎
の形状や形式 9についての検討を行ってきた。異なる基樥形式につ いて同一の条件下で比較した系統的な分析例は、三浦等 ${ }^{100}$ の軸対称 有限要素法による解析的検討があるが、3 次元解析による検討は殆 どない。また、上述の各種要因の影響を要因別に検討した例も見ら れない。

そこで、本論では、地表面直接基礎、地表面杭基礎、パイルド • ラフト基礎、根入れを有する直接基礎、根入れを有する杭基礎を対 象に基碗形式による動的相互作用特性の違いを分析する。さらに、 個々の基礎形式に対して、以下の要因の影響を検討することにする。

(1) 杭基礎の場合の支持層と表層地盤の $\mathrm{S}$ 波速度比

(2) 杭基礎の場合の杭頭条件（剛接合とピン接合）

（3）杭基礎の場合の杭端条件（拡底の有無）

(4) パイルド・ラフト基礎のラフトの拡大の有無

(5) 根入れを有する杭基礎の基礎底面の接触条件 これらの検討により、限界耐力計算法で利用されているような簡易 な相互作用ばねへの置換に際しての基礎的知見を得る。

\section{2 解析手法}

解析法は、既出の論文と同様であり 8,9 、基本的に Lysmer らによ る SASSI ${ }^{11)}$ 考え方に準拠し、薄層法と有限要素法を、容積法を用 いた動的サブストラクチャー法により結合した方法である。ここで は、図 1 に示すように、根入れ基礎十基䂭部と周辺地盤とを分離し
*1 中国湖南大学 講師 ·博士 (工学)

*2 名古屋大学大学院環境学研究科 教授. 工博
Lecturer, Hunan University, China, Dr. Eng.

Prof., Graduate School of Environmental Studies, Nagoya Univ., Dr. Eng. 


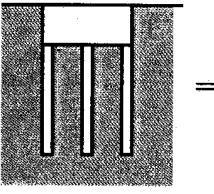

(a)杭一地盤系

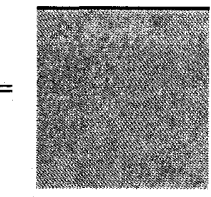

(b)自由地盤

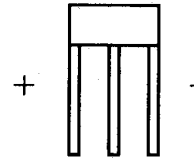

(c)構造物

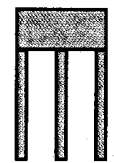

(d)原地盤
図 1 容積法による杭一地盤系のモデル

て解析を行い、インピーダンスや基碄 入力動を算定する。薄層法には、線形 の内挿関数を利用し、薄層底面境界に はパラキシャル境界 12)を適用している。 グリーン関数としては、ディスク加振 解（加振点と受振点が同一鉛直軸上の 場合）と点加振解を用いている。杭の 拡底を考慮する場合には、グリーン関 数の相反定理が成り立たないため、杭 部と拡底部のグリーン関数の平均値を

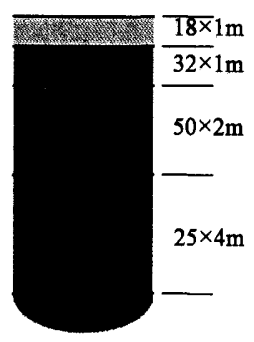

Paraxial Boundary

図 2 地盤の薄層モデル 用いている。また、根入れ部原地盤は

3 次元アイソパラメトリック要素でモデル化して根入れ部地盤を除 去し、杭はせん断変形を考虑した梁要素を用いてモデル化する。な お、杭一地盤間の力の授受は杭周面で行われるため、杭の断面積を 考慮したグリーン関数の算定が必要となる。本論では、ディスク加 振解を用いることによりこの点を考虑しているが、別途、リング加 振解を用いた検討も行い、結果に差異が小さいことを確認している。 また、杭のモデル化については、地表面杭基喽の場合を対象として、 杭の剛性・質量を地盤のそれと一致させた検討を行い、自由地盤の 動きを再現できることを確認している。合わせて、既往の解析結果 2),3),5,7)を再現できることを確認している。地盤は二層地盤を想定し、 薄層の分割は、対象振動数範囲での波長の変化を表現するため、図 2 に示すように $18 \times 1 \mathrm{~m}+32 \times 1 \mathrm{~m}+50 \times 2 \mathrm{~m}+25 \times 4 \mathrm{~m}$ に分割した。

無質量剛基礎一杭一地盤系の振動数領域での運動方程式は、式(1) のように書くことができる。

$\left([K]^{G}+[S]^{S}-[S]^{E}\right)\{u\}=\{F\}$

ここに、

$[S]=[K]-\omega^{2}[M]$

また、 $[K] 、[M] 、\{u\}$ はそれぞれ剛性マトリクス、質量マトリクス及 び変位べクトルである。上添字 G、S、E はそれぞれ自由地盤、剛基 礎及び杭、基礎及び杭に置換した原地盤を意味する。ただし、原地 盤の剛性マトリクスは、杭については梁要素で評価し、根入れ部に ついてはソリッド要素で評価する。

無質量剛基礎のインピーダンスを算出するために、全ての自由度 を基礎の自由度(下添え字 F)とその以外の自由度(下添え字 O)に分け ると、式(1)を以下のように書くことができる。

$\left[\begin{array}{ll}{\left[S_{F F}\right]} & {\left[S_{F O}\right]} \\ {\left[S_{O F}\right]} & {\left[S_{O O}\right]}\end{array}\right]\left\{\begin{array}{l}\left\{u_{F}\right\} \\ \left.u_{O}\right\}\end{array}\right\}=\left\{\begin{array}{l}\left\{F_{F}\right\} \\ \left\{F_{O}\right\}\end{array}\right\}$

容積法を用いた動的サブストラクチャー法の考え方を利用して、 式(2)を構筑した後、下添え字が O の自由度を消去することにより、 無質量剛基礎に対する 6 自由度の運動方程式に変換する。これによ り、基礎のインピーダンスは式(3)のように評価することができる。
$\left[K_{F}\right]=[T]^{T}\left[S_{F F}\right]^{*}[T]$

ここに、

$\left[S_{F F}\right]^{*}=\left[S_{F F}\right]-\left[S_{F O}\right]\left[S_{O O}\right]^{-1}\left[S_{O F}\right]$

である。また、[T]は、剛基礎の変位拘束条件を表す座標変換マト リクスである。

基礎入力動は、外力を式(4)で表せることから、これを式(2)に代入 して、基磷の応答を評価している。

$$
\left\{\begin{array}{l}
\left\{F_{F}\right\} \\
\left\{F_{O}\right\}
\end{array}\right\}=[K]^{G}\{u\}_{G}=\left[\begin{array}{ll}
{\left[K_{F F}\right]^{G}} & {\left[K_{F O}\right]^{G}} \\
{\left[K_{O F}\right]^{G}} & {\left[K_{O O}\right]^{G}}
\end{array}\right]\left\{\begin{array}{l}
\left\{u_{F}\right\}_{G} \\
\left\{u_{O}\right\}_{G}
\end{array}\right\}
$$

ここに、 $\left\{u_{F}\right\}_{\mathrm{G}}$ と $\left\{u_{O}\right\}_{\mathrm{G}}$ は地震波入射時の自由地盤の变位応答である。

\section{3 杭基磷}

\section{1 支持展の硬さの影雷}

支持層の硬さが杭基砋のインピーダンスと基㸴入力動に与える影 響を検討する。図 3 に示すように、等間隔に正方形配置した場所打 ち鉄筋コンクリート杭を想定する。杭は支持層に $2 \mathrm{~m}$ 根入れされて いるとする。杭と表層地盤の主要な解析パラメータを表 1 に示す。 表 2 に示すように、支持地盤の表層地盤に対する $\mathrm{S}$ 波速度比： $V_{\mathrm{S} 2} / V_{\mathrm{S} 1}$ が 1 (一様地盤の摩撩杭に相当)、2、4 と增加する場合について、 インピーダンスと基硌入力動の変動を考察する。ただし、基礁部は 無質量とし、杭頭と基磷は凪接とする。また、地震波は鉛直下方か ら S 波が入射する場合を考える。この検討は、摩㨲杭と支持杭の差 異を検討することにも慗がる。

図 4 に支持層の硬さがインピーダンスに与える影響を示す。水平 成分は、2 層地盤では逸散波の重複反射により振動数による変動が
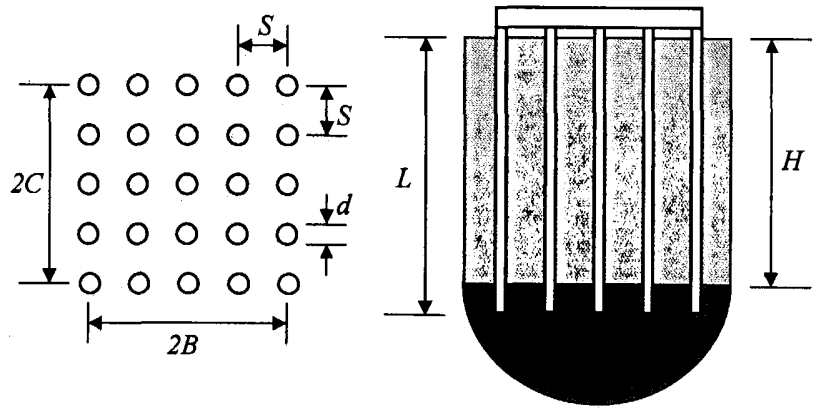

図 3 杭基礎と地盤のモデル

表 1 杭と表層地盤の解析パラメータ

\begin{tabular}{|l|l|c|}
\hline \multicolumn{2}{|c|}{ 杭 } & 表層地盤 \\
\hline 杭本数 $N=5 \times 5$ & $E_{\mathrm{P}}=2.1 \times 10^{7} \mathrm{kN} / \mathrm{m}^{2}$ & $V_{\mathrm{S} 1}=150 \mathrm{~m} / \mathrm{s}$ \\
\hline$d=1.5 \mathrm{~m}, S=7.5 \mathrm{~m}$ & $v_{\mathrm{P}}=1 / 6$ & $\rho_{1}=1.5 \mathrm{t} / \mathrm{m}^{3}$ \\
\hline$L=20 \mathrm{~m}$ & $\rho_{\mathrm{p}}=2.4 \mathrm{t} / \mathrm{m}^{3}$ & $v_{1}=0.45, \quad h_{1}=0.03$ \\
\hline $2 B=2 C=30 \mathrm{~m}$ & $h_{\mathrm{P}}=0.03$ & $H=18 \mathrm{~m}$ \\
\hline
\end{tabular}

\begin{tabular}{|c|c|c|}
\multicolumn{2}{c}{ 表 2 支持層の解析パラメータ } \\
\hline CASE1 & CASE2 & CASE3 \\
\hline$V_{\mathrm{S} 2}=150 \mathrm{~m} / \mathrm{s}$ & $V_{\mathrm{S} 2}=300 \mathrm{~m} / \mathrm{s}$ & $V_{\mathrm{S} 2}=600 \mathrm{~m} / \mathrm{s}$ \\
\hline$\rho_{2}=1.5 \mathrm{t} / \mathrm{m}^{3}$ & $\rho_{2}=1.8 \mathrm{t} / \mathrm{m}^{3}$ & $\rho_{2}=2.1 \mathrm{t} / \mathrm{m}^{3}$ \\
\hline$\nu_{2}=0.45$ & $\nu_{2}=0.45$ & $\nu_{2}=0.45$ \\
\hline$h_{2}=0.03$ & $h_{2}=0.03$ & $h_{2}=0.03$ \\
\hline
\end{tabular}




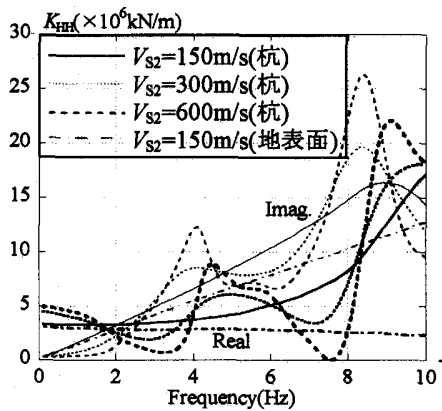

(a) 水平

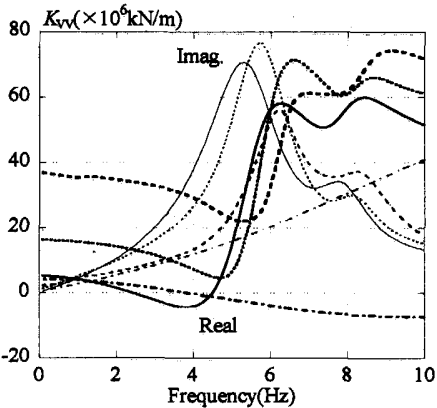

(b) 上下

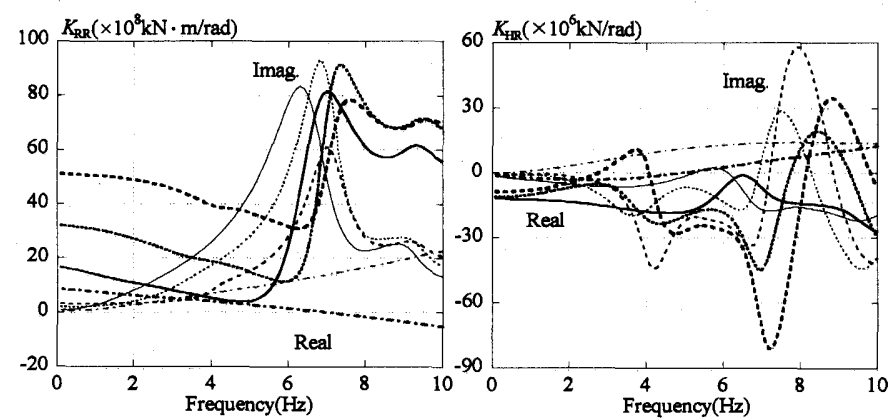

(c) 回転

（d）水平一回転

図 4 支持層の硬さがインピーダンスに与える影響

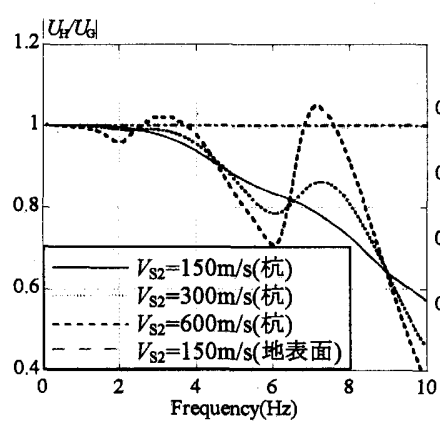

（a）水平

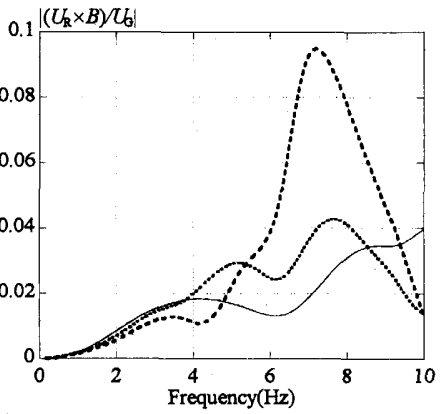

(b) 回転

図 5 支持層の硬さが基礎入力動に与える影響

生じており、支持層が硬いほど変動の振幅が大きくなっている。こ れに対し、上下成分と回転成分は、支持層が硬くなるに従い、杭端 での抵抗の増大により低振動数域で実部が増加し、逸散波の重複反 射により虚部が減少している。結果として、上下及び回転インピー ダンスの等価な减衰は小さくなる。また、支持層の硬さに拘わらず、 上下及び回転成分では、高振動数域で Out-of-phase 現象 ${ }^{13)}$ と呼ばれ る杭間隔に依存したピークが顕著に現れている。支持杭と摩擦杭の 差という観点では、その差は、上下と回転成分に顕著であると言え る。参考のために、図 4 中には CASE1 に相当する半無限一様地盤上 の地表面直接基礎の結果を示すが、水平成分は概ね地表面值接基礎 の結果に対応している。また、杭長さを $20 \mathrm{~m}$ とした杭の鉛直剛性か ら求めた上下及び回転ばねは、 $46.4 \times 10^{6} \mathrm{kN} / \mathrm{m} 、 52.2 \times 10^{8} \mathrm{kNm}$ であり、 CASE3 の静的ばねの值に近い。

図 5 に支持層の硬さが基礎入力動に与える影響を示す。水平・上 下成分共に、支持層が存在すると、水平インピーダンスと同様に表 層内の波動の重複反射による振動数变動を示し、支持層が硬いほど 変動度合いが大きくなっている。

\section{2 表層地盤の硬さの影掣}

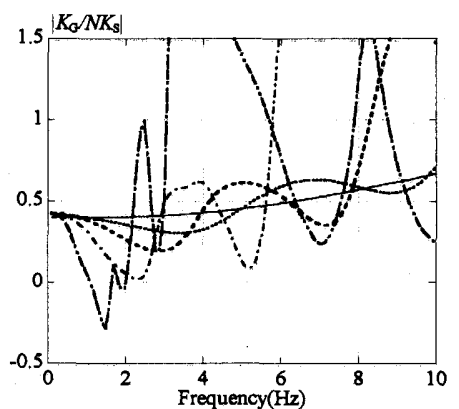

(a) 地盤ばね(水平)

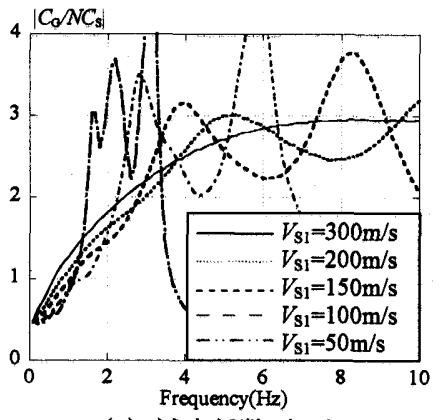

(b) 減衰保数(水平)

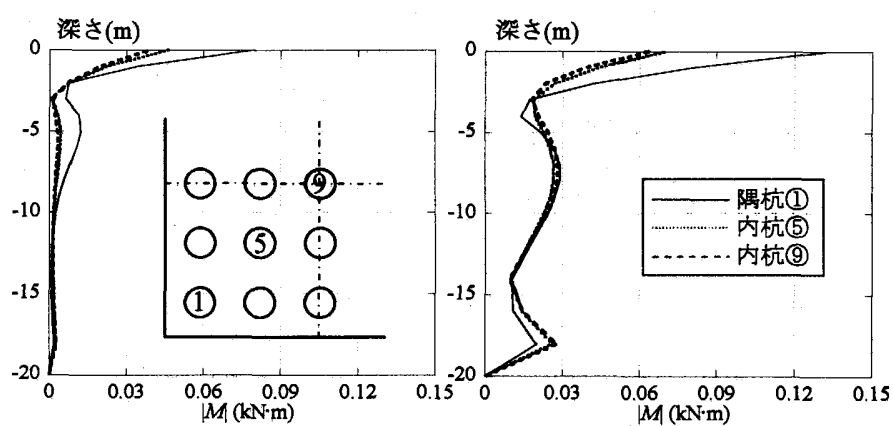

$\begin{array}{ll}\text { (a) } V_{\mathrm{S} 1}=200 \mathrm{~m} / \mathrm{s}(2.0 \mathrm{~Hz}) & \text { (b) } V_{\mathrm{S} 1}=100 \mathrm{~m} / \mathrm{s}(2.0 \mathrm{~Hz})\end{array}$

図 7 水平加振 $(1 \mathrm{kN})$ による杭の曲げモーメント

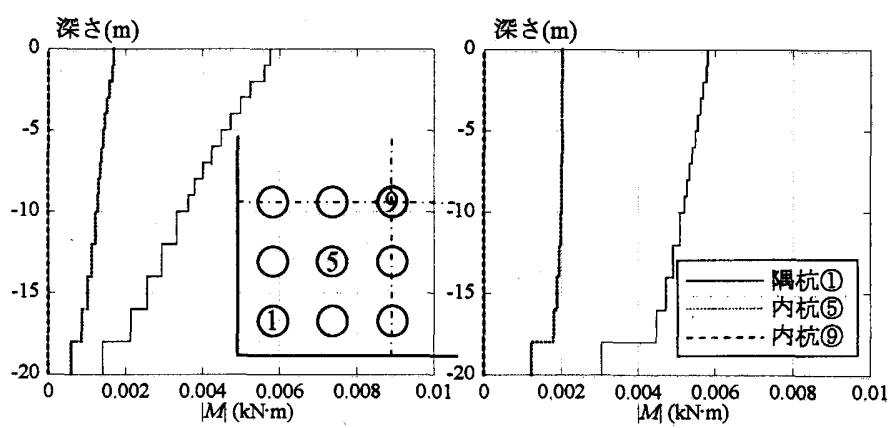

(a) $V_{\mathrm{Sl}}=200 \mathrm{~m} / \mathrm{s}(2.0 \mathrm{~Hz})$

(b) $V_{\mathrm{S} 1}=100 \mathrm{~m} / \mathrm{s}(2.0 \mathrm{~Hz})$

図 8 回転加振 $(1 \mathrm{kNm})$ による杭の軸力

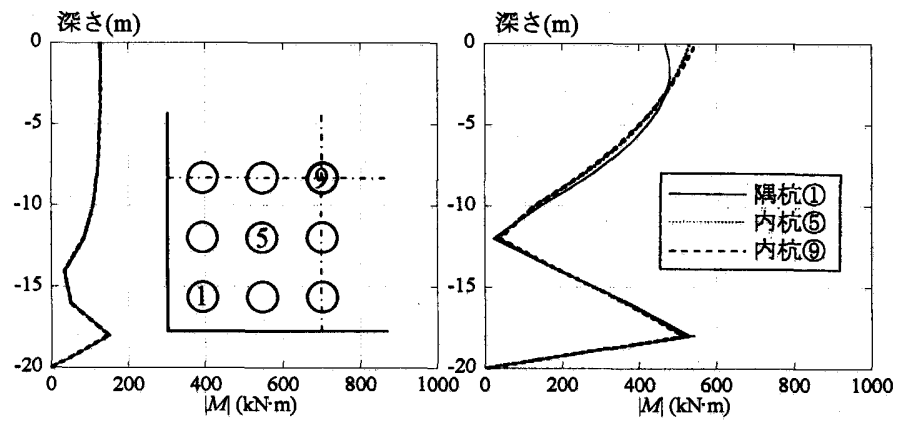

(a) $V_{\mathrm{S} 1}=200 \mathrm{~m} / \mathrm{s}(2.0 \mathrm{~Hz})$

(b) $V_{\mathrm{S} 1}=100 \mathrm{~m} / \mathrm{s}(2.0 \mathrm{~Hz})$

図 9 入力地震(地表面 $100 \mathrm{gal}$ )による杭の曲げモーメント

つぎに、表層地盤の硬さが群杭勃率と杭応力に与える影響を检討 する。支持層の $\mathrm{S}$ 波速度を $V_{\mathrm{S} 2}=300 \mathrm{~m} / \mathrm{s}$ と固定し、表層地盤の $\mathrm{S}$ 波速 度 $V_{\mathrm{S} 1}$ をそれぞれ $300 \mathrm{~m} / \mathrm{s} 、 200 \mathrm{~m} / \mathrm{s} 、 150 \mathrm{~m} / \mathrm{s} 、 100 \mathrm{~m} / \mathrm{s}$ および $50 \mathrm{~m} / \mathrm{s}$ と する。

図 6 に、表層地盤の硬さが群杭効率に与える影響を示す。群杭、 単杭の水平インピーダンスをそれぞれ $K_{\mathrm{G}}+i \omega C_{\mathrm{G}} 、 K_{\mathrm{S}}+i \omega C_{\mathrm{S}}$ と記し、 群杭効率を算定する（わり算は、各振動数の群杭の結果を単杭（杭 
頭回転拘束）の結果 $\times$ 杭本数で除している)。図より、地盤ばねに関 しては、静的な群杭効率に与える表層地盤の硬さの影響は小さく、 表層が軟弱なほど、低振動数域での群杭効率が大きく低下すると共 に、振動数变動が大きくなり、ばねの群杭效率は 1 を中心に変動す るようになる。一方、減衰に関しては、杭で囲まれた地盤が一体で 振動するようになるため、群杭効率は 1 を上回るが、表層が軟弱に なるとその効果が減じられている。

図 7 9 に、表層 $\mathrm{S}$ 波速度が $200 \mathrm{~m} / \mathrm{s}$ と $100 \mathrm{~m} / \mathrm{s}$ の場合の、水平加 振時の杭の曲げモーメント、回転加振時の杭の軸力および地震入力 による杭の曲げモーメントの振幅を比較する。図 7 より、杭頭水平 加振の場合には、内杭よりも隅杭で曲げモーメントが大きく、表層 地盤が軟らかくなるに従って、杭の曲げモーメントが大きくかつ反 曲点が梁くなり、梁くまで力が伝達されている。図 8 より、基礎に 回転加振力が作用する場合には、杭頭の軸力負担分布は基硔中心に 対して三角形にはならず、隅杭(1)は内杭(5)の 3 倍程度になっている。 また、表層地盤が軟らかくなるに従って、杭頭の軸力が染さ方向に 低減しにくくなり、杭端の寄与が大きくなっている。図 9 より、S 波入射の場合には、表層が軟弱な場合には杭頭で隅杭よりも内杭で 曲げモーメントが大きく、層境界で大きなモーメントを生じている。

\section{3 杭頭条件の野}

杭頭条件がインピーダンスと基喽入力動に 与える影響を検討する。図 10 に示すように、 杭頭と基礎の接合条件が剛接合およびピン接 合の 2 ケースを想定する。杭と地盤の主要な 解析パラメータは表 1 と表 2 の CASE2 とする。 インピーダンスと基礎入力動を図 11 及び 図 12 に示す。水平成分は、ピン接合になると 実部・虚部ともに大きく減少するが、上下成 分と回転成分には杭頭条件の影響はほとんど ないことが分かる。一方、基礎入力動は、ピ
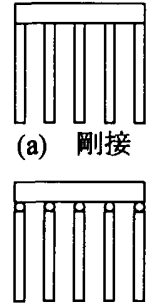

(b) ピン

図 10 杭頭条件 (a) 㓮接 ン接合になると、水平成分は増加し、回転成分は減少しており、地 表面直接基礎の状態に近づいている。水平成分で 1 を超える場合が あることは注意を要する。近年、杭頭の接合条件を柔にすることに よって杭モーメントを低減する提案が各所でされているが、杭応力 の低減の代わりに建物応答を増加させる傾向があることに留意する ベきである。

\section{4 杭の搪底の影辢}

次に、図 13 に示すように杭の拡底がイ ンピーダンスと基礎入力動に与える影響を 検討する。杭と地盤の解析パラメータは表 1 と表 2 の CASE2 とし、杭頭は剛接、拡 底部の直径は $d_{1}=2.5 \mathrm{~m}$ とする。

図 14 に示すように、インピーダンスは、 上下成分と回転成分で拡底の有無による差 が若干認められるが、水平成分と水平一回 転連成成分では、この差は極めて小さい。

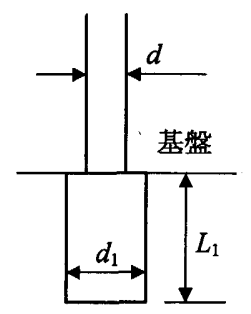

図 13 拡底のモデル
これは、図 7 8に示したように、水平成分は回転成分に比べて杭端 の抵抗の寄与が小さいためである。また、図 15 に示すように、基礎

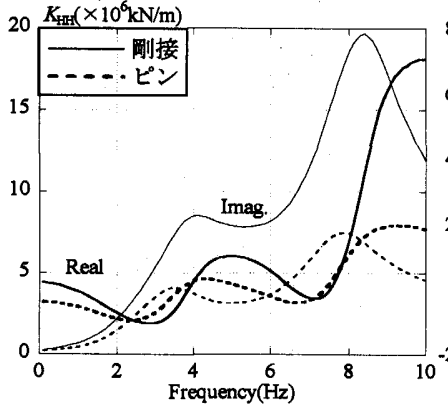

(a) 水平

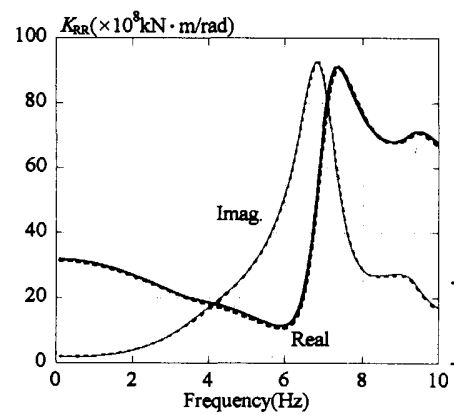

(c) 回転

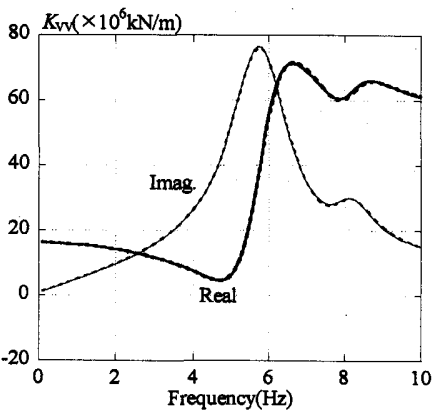

(b) 上下

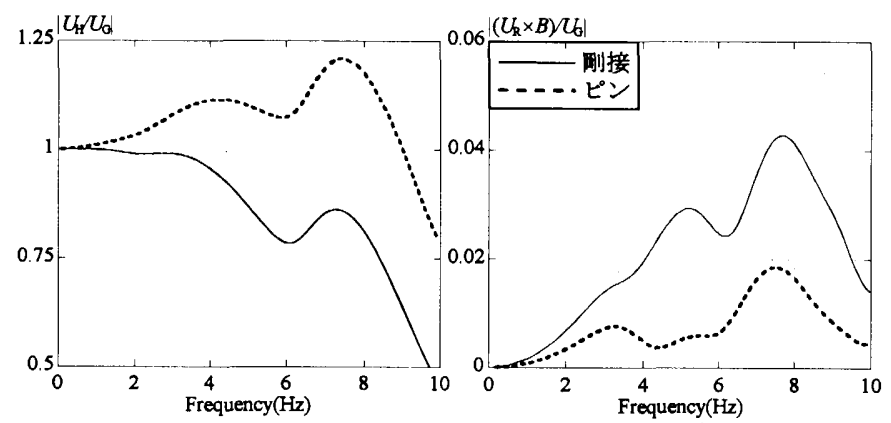

(a) 水平

(b) 回転

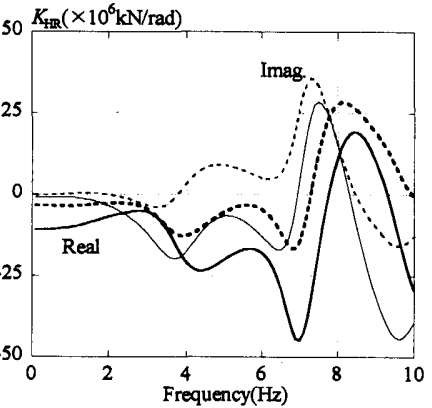

(d) 水平一回転

図 12 杭頭条件が基礎入力動に与える影響

入力動には搪底の影響は非常に小さい。これらの結果から、支持杭 の動特性を考える際には、杭端の拡底の効果を無視しても大きな問 題にはならないことが分かる。ただし、表層部が非線形化によって 剖性低下しており、杭一地盤間の摩擦が期待できない場合には、拡 底の影響はより大きくなる。

4 パイルド・ラフト基礎

基礎底部と地盤を密着させた場合をパイルド・ラフト基礎と考え、 非接触と仮定した摩擦杭基碗、地表面直接基礎と、結果を比較する。 また、ラフトの拡大部分の影響についても検討を加える。解析に用 いたパラメータを表 3 に示す。

\section{1 ラフトの拡大部分の影策}

図 16 に示すように、ラフトの拡大部分がインピーダンスと基礎 入力動に与える影響を検討する。ラフトの拡大部分は $S_{1}=1.5 \mathrm{~m}$ とす る。基礎は無質量とし、杭頭と基礎は剛接とする。図 17 にインピー ダンスを、図 18 に基礎入力動を、ラフトの拡大の有無を比較して示 す。図より、高振動数域でインピーダンスの実部、基礎入力動の回 転成分に相違がみられるが、低振動数城ではラフト拡大の影響は非 


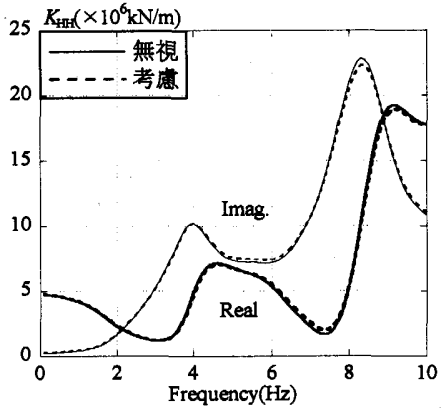

(a) 水平

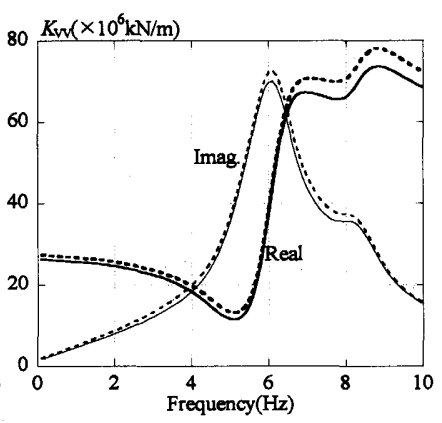

(b) 上下

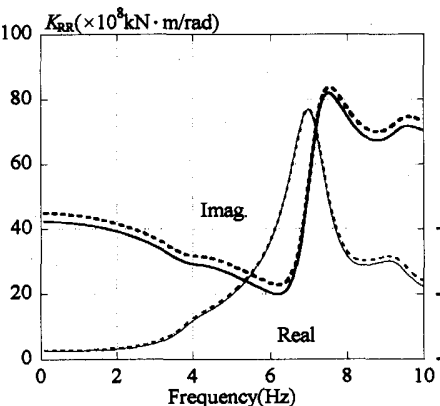

(c) 回転

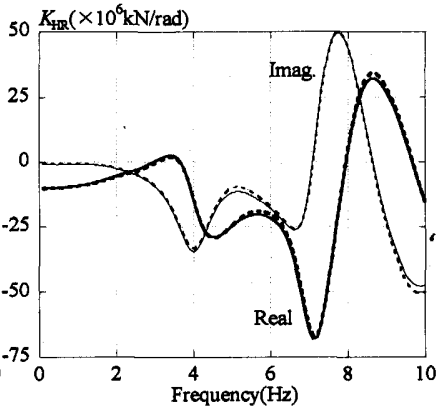

（d）水平一回転
図 14 杭の広底がインピーダンスに与える影響

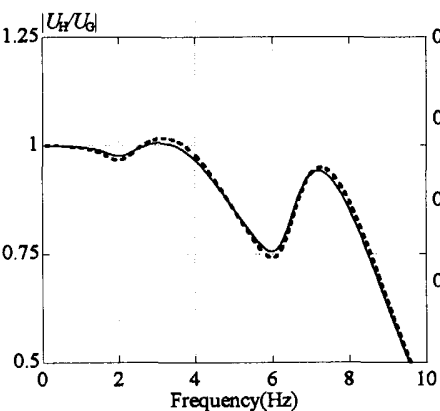

(a) 水平

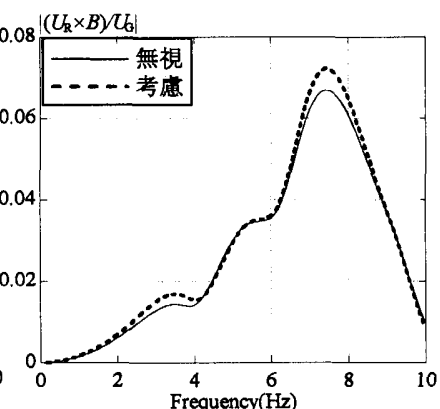

(b) 回転
図 15 杭の拡底が基磷入力動に与える影響

常に小さい。この結果から、一般の建物の 1 次固有振動数程度以下 の振動数範囲であれば、 $1.5 \mathrm{~m}$ 程度のラフト部分の拡大の影響は概ね 無視できることが分かる。

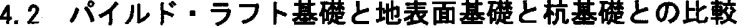

パイルド・ラフト基礎を地表面基礎や杭基礎と比較する。パイル ド・ラフト基礎のパラメータは 4.1 節と同様とし、ラフト㹡大部は 無視する。また、地表面基礎はパイルド・ラフト基礎と同じサイズ で、 $2 B \times 2 C=30 \mathrm{~m} \times 30 \mathrm{~m}$ とする。

図 19 に、3 種類の基礎形式のインピーダンスを比較して示す。水 平成分は、低振動数域では三者がよく対応し、パイルド・ラフト基 礎、杭基整、地表面基磷の順に值が小さくなっている。高振動数域 では三者の差は拡大しているが全体的傾向は類似している。これに 対し、回転、上下成分は、杭の寄与が大きいため、低振動数域で杭 基礎とパイルド・ラフト基礎がほぼ一致している。ただし、パイル ド・ラフト基礎の場合には、高振動数域に見られる杭間隔に依存す る Out-of-phase 現象が抑制されている。これらの結果は、限界耐力 計算法で、杭基礎の水平地盤ばねの算定に際して、地表面基硕の地
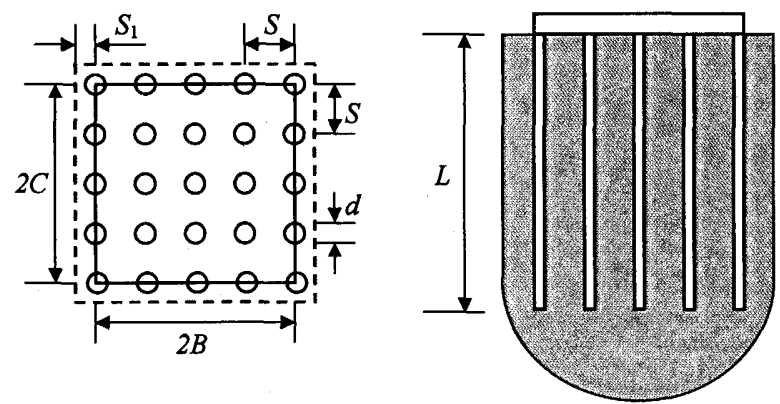

図 16 パイルド・ラフト基磷のモデル

表 3 パイルド・ラフト基礎の解析パラメータ

\begin{tabular}{|l|l|c|c|}
\hline \multicolumn{2}{|c|}{ 杭 } & ラフト & 地盤 \\
\hline 本数 $N=5 \times 5$ & $E_{\mathrm{P}}=2.1 \times 10^{7} \mathrm{kN} / \mathrm{m}^{2}$ & 床: $2 B=30 \mathrm{~m}$ & $V_{\mathrm{S}}=150 \mathrm{~m} / \mathrm{s}$ \\
\hline$d=1.5 \mathrm{~m}$ & $v_{\mathrm{P}}=1 / 6$ & 床: $2 C=30 \mathrm{~m}$ & $\rho=1.5 \mathrm{t} / \mathrm{m}^{3}$ \\
\hline$S=7.5 \mathrm{~m}$ & $\rho_{\mathrm{P}}=2.4 \mathrm{t} / \mathrm{m}^{3}$ & 拡大: $S_{1}=1.5 \mathrm{~m}$ & $v=0.45$ \\
\hline$L=20 \mathrm{~m}$ & $h_{\mathrm{P}}=0.03$ & & $h=0.03$ \\
\hline
\end{tabular}

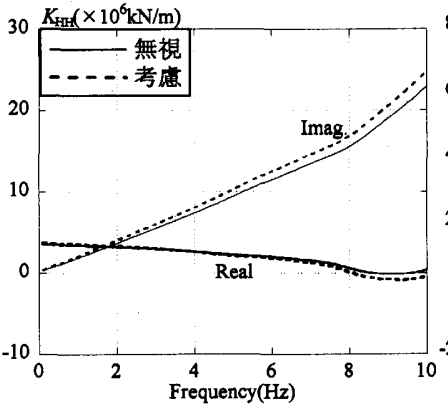

（a）水平

(c) 回転

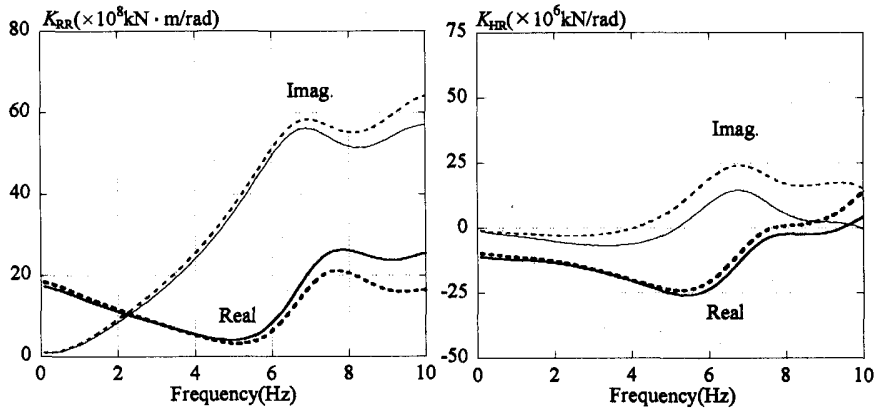

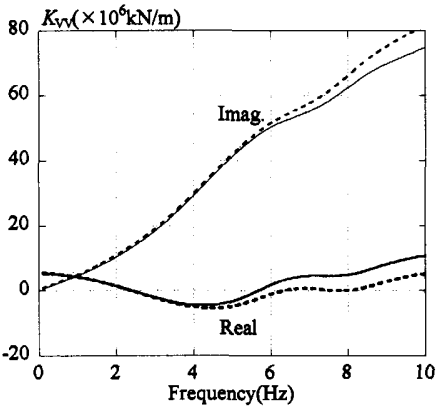

(b) 上下

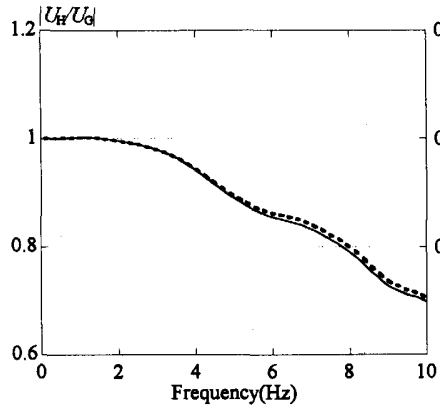

(a) 水平 （d）水平一回転

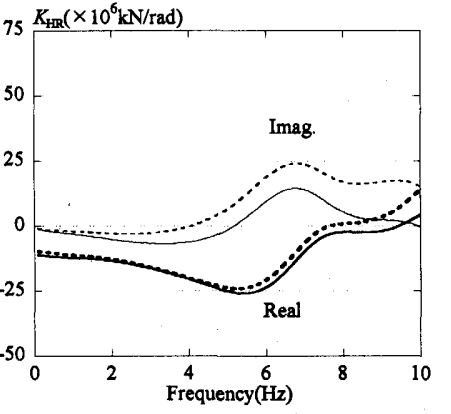

ダンスに与える影響

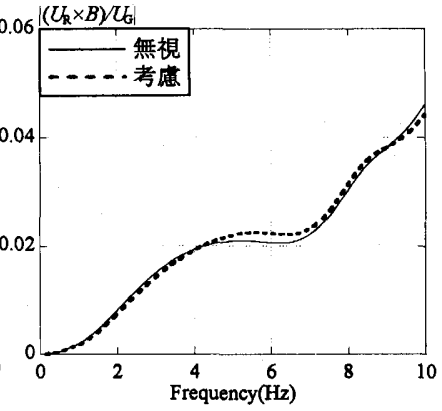

(b) 回転
盤ばねを準用していることの妥当性をある程度支持していると解釈 できる。

図 20 には、対応する基䃈入力動を示す。パイルド・ラフト基礎の 


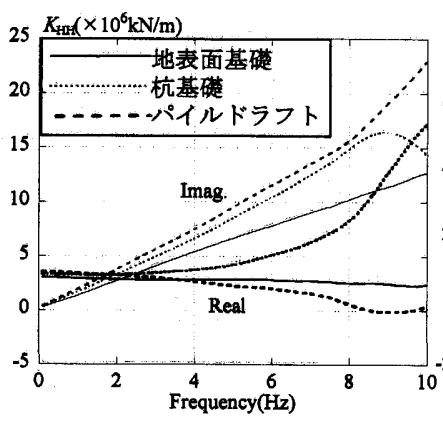

(a) 水平

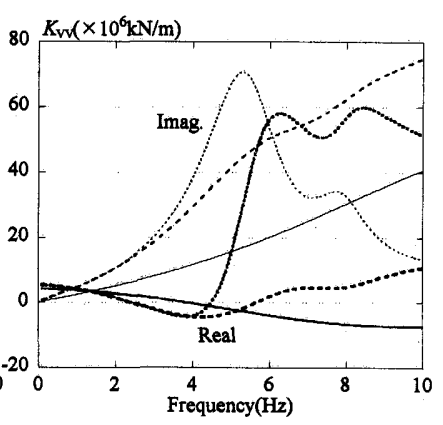

(b) 上下

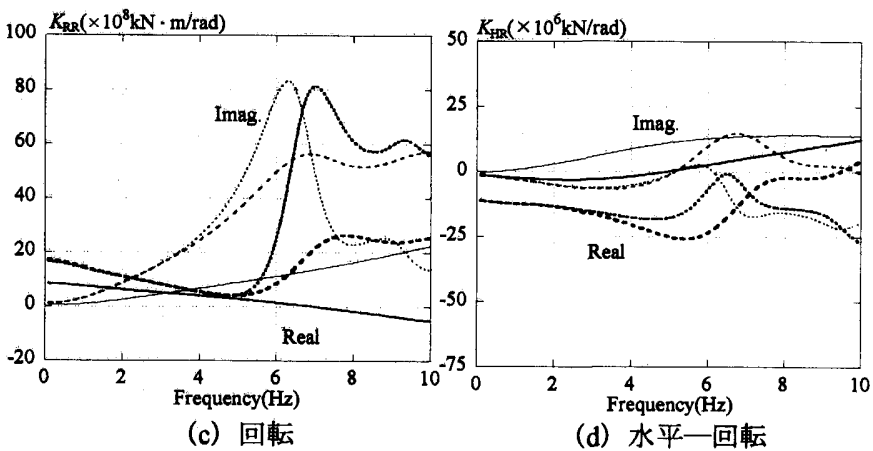

図 19 地表面基礎、杭基硽とパイルド・ラフト基硭のインピ

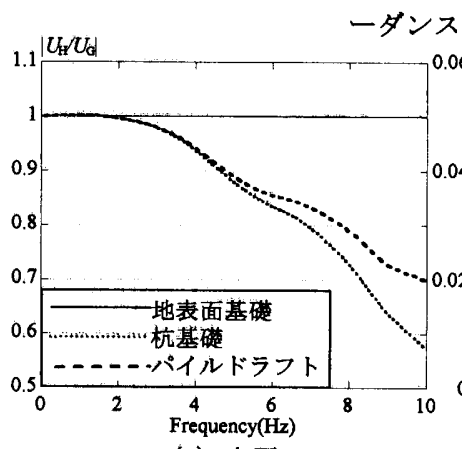

(a) 水平

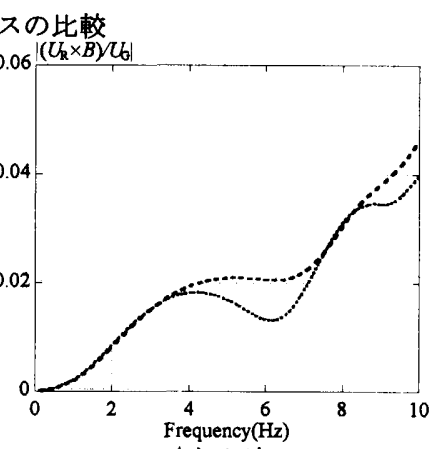

(b) 回転
図 20 地表面基礎、杭基硠とパイルド・ラフト基礎の基䃈入 力動の比較

結果は杭基整と概ね一致する結果を示している。

以上の結果から、パイルド・ラフト基礎は第一次近似として、杭 基礎の結果を利用することが可能であると考えられる。

\section{5 根入れを有する杭基碄}

つぎに、図 21 に示すように、根入れを有する杭基礎について検討 する。地盤、杭、根入れ部の主要な解析パラメータは、表 4 、表 5 に示す通りである。

\section{1 根入れ底部の接触条件の影僌}

最初に、基礎底部の接触条件の影響について考察する。ここでは、 根切り底の埋土の影響を検討するために、図 22 に示すように、基礎 底部が原地盤と密着・非接触の 2 ケースと、埋土が存在するケース の計 3 ケースを考える。ただし、地盤は一様地盤と想定している。

インピーダンスと基礎入力動を、図 23、図 24 に示す。高振動数 域では、非接触の場合のみ差異が生じているが、低振動数では三者 が概ね一致しており、基礎底面の接触条件が、相互作用特性に与え る影響は大きくはないことが分かる。

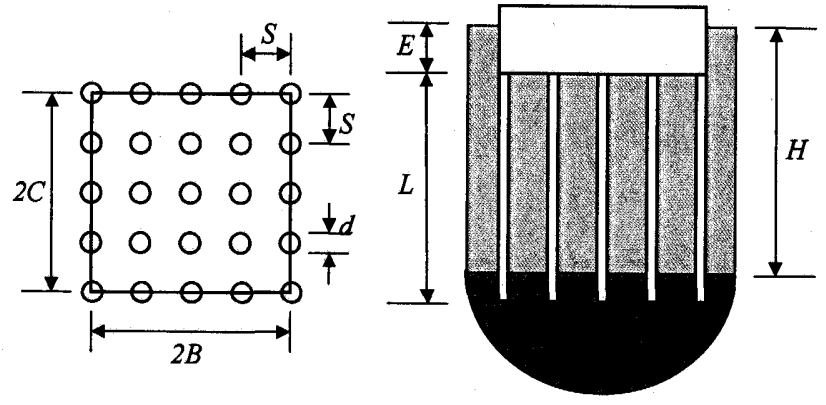

図 21 根入れを有する杭基礪のモデル

表 4 根入れを有する杭基礎の解析パラメータ

\begin{tabular}{|l|l|c|}
\hline \multicolumn{2}{|c|}{ 杭 } & 根入れ部 \\
\hline 本数 $N=5 \times 5$ & $E_{\mathrm{P}}=2.1 \times 10^{7} \mathrm{kN} / \mathrm{m}^{2}$ & $2 B=30 \mathrm{~m}$ \\
\hline$d=1.5 \mathrm{~m}$ & $v_{\mathrm{P}}=1 / 6$ & $2 C=30 \mathrm{~m}$ \\
\hline$S=7.5 \mathrm{~m}$ & $\rho_{\mathrm{p}}=2.4 \mathrm{t} / \mathrm{m}^{3}$ & $E=4 \mathrm{~m}$ \\
\hline$L=16 \mathrm{~m}$ & $h_{\mathrm{P}}=0.03$ & \\
\hline
\end{tabular}

表 5 地盤の解析パラメータ

\begin{tabular}{|c|c|}
\hline 表層地盤 & 支持層 \\
\hline$V_{\mathrm{S} 1}=150 \mathrm{~m} / \mathrm{s}$ & $V_{\mathrm{S} 2}=300 \mathrm{~m} / \mathrm{s}$ \\
\hline$\rho_{1}=1.5 \mathrm{t} / \mathrm{m}^{3}$ & $\rho_{2}=1.8 \mathrm{t} / \mathrm{m}^{3}$ \\
\hline$v_{1}=0.45$ & $h_{2}=0.45$ \\
\hline$h_{1}=0.03$ & $h_{2}=0.03$ \\
\hline
\end{tabular}

また、図 19〜20 と比較すると、根入れの存在によってインピー ダンスはいずれの方向成分も実部・虚部共に増加しているが、直接 基礶の場合ほど根入れによる変動は大きくはない。根入れの存在に より、上下及び回転方向成分に見られる杭間の距離によって生じる 振動数変動が减少している。これは、根入れの存在により杭部の寄 与が減少することと、基䃈底部・地盤接触時にマット部の拘束効果 が増加するためと思われる。また、基礎入力動は、根入れによる水 平動低减効果と回転動增大効果が現れている。

\section{2 根入れ基礎と根入れを有する杭基碚の比較}

根入れを有する杭基䃈のインピーダンスと基礎入力動を、根入れ を有する直接基礎および地表面杭基礎の結果と比較する。ただし、 図 25 に示すように、根入れを有する杭基礎では基礎底部と地盤が密 着していると仮定し、直接基礎と杭基䃈は根切りの有無の二者を考 える。

インピーダンスは、図 26 に示すように、水平成分と回転・上下 成分では傾向が異なる。水平成分では、根入れを有する杭基礎の結 果は直接基礎と良く対応している。これに対し、上下成分と回転成 分は、根入れを有する杭基礎は低振動数域で杭基礎とよく対応して いる。ただし、杭基礎に見られる杭間距離による伴う振動数変動は 根入れの存在により抑制されている。また、杭基礎については、特 に低振動数域では根切りの有無による差は無視できる量である。水 平成分と、回転・上下成分との差異は、インピーダンスに及ぼす杭 部と根入れ側面部との寄与度が、方向成分によってことなることに 起因している。水平成分に関しては、杭の曲げ剛性が小さいため、 地盤の圧縮・引張抵抗に伴う根入れ側面部の剛性寄与が支配的にな る。波動逸散に関しても根入れ部の前後面からは P 波が逸散するた 


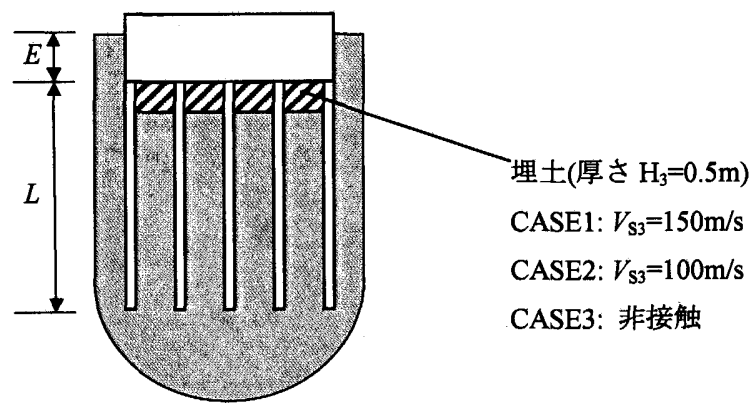

図 22 基礎底面下の埋土を考慮したモデル

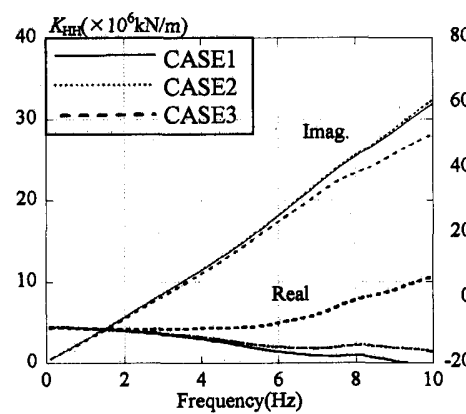

（a）水平

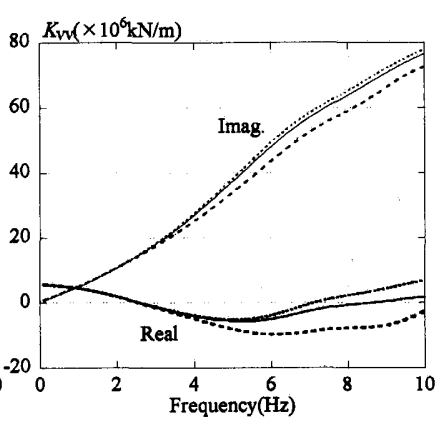

(b) 上下

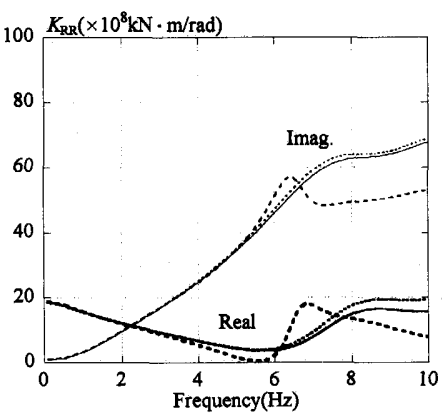

(c) 回転

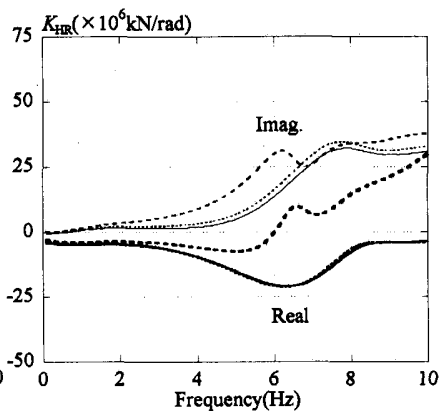

(d) 水平一回転
図 23 根入れ底部の接触条件がインピーダンスに与える影響

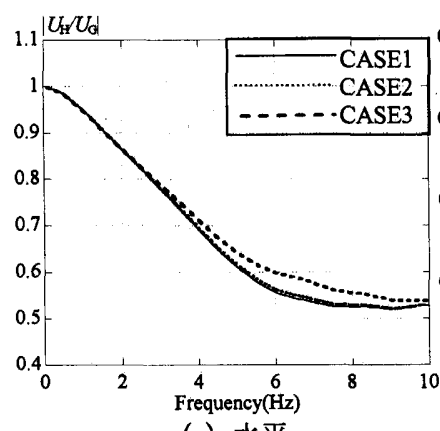

(a) 水平

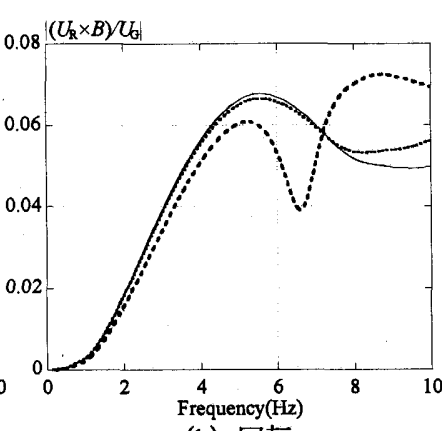

(b) 回転
図 24 根入れ底部の接触条件が基礎入力動に与える影響

め大きな波動インピーダンスが期待できる。これに対し、上下およ び回転成分では、杭の軸剛性が大きく、杭部の寄与が大きいため杭 基整との対応が良くなる。また、杭間距離に伴う振動数変動の抑制 については、パイルド・ラフトの場合と同様に、マット基礎による 変位拘束効果によると考えられる。

つぎに、図 27 に基䃈入力動を比較して示す。CASE5〜 6 は、根 入れに伴う入力低減効果を期待できないため、他の四者と結果が異 なる。根入れを有する四者を比較すると、根入れを有する杭基礎は、
根入れ直接基礎と根切りのある杭基礎の結果の中間の結果を与えて いる。第一次近似としては、限界耐力計算法のように根入れ基礎の 基礎入力動を代用することもあり得ることを示している。

\section{6 まとめ}

本論では、様々な基礎形式の動的相互作用特性を系統的に分析す ると共に、直接基礎、杭基礎、パイルド・ラフト基礎の結果を比較 し、地盤、杭、接触条件などの具体的な要因の影響を検討した。得 られた主な知見は以下の通りである。

(1)杭基整の水平インピーダンスは概ね同サイズの直接基礎のそれと 対応する。また、支持層の存在により、杭基磼のインピーダンス は、水平成分では、波動の重複反射による振動数変動が生じ、上 下成分と回転成分では、低振動数域で実部が増大・虚部が減少し、 高振動数域で杭間隔に伴う振動数変動が生じる。基䃈入力動に関 しては、水平成分は支持層剛性による変動は小さいが、回転成分 は支持層の存在に伴う波動の重複反射により励起されやすくなる。 (2)杭忘力は、杭頭水平加振時には、表層地盤が柔らかいほど杭の曲 げモーメントが大きくなり、深部まで応力が伝達されるが、杭端 ではほぼゼロとなる。これに対し、回転加振の場合、軸力は杭端 まで伝達される。また、隅杭と内部の杭との応力負担の仕方は、 杭頭加振では隅杭で大きく、地盤振動時はほぼ均等に負担する。 さらに、表層地盤の硬さは静的群杭効率に余り影響しないが、表 層が軟弱になると重複反射に伴って群杭効率の振動数変動が顕著 になる。

(3)杭頭条件がインピーダンスに及ぼす影響は水平成分で大きく、ピ ン接合時は実部・虚部ともに大幅に減少するが、上下成分・回転 成分で影響はほとんどない。基硕入力動は、ピン接合の場合は剛 接に比べて水平成分が増大し、回転成分は減少する。杭頭の接合 部を柔らかくすることは杭応力の低減には寄与するが建物への入 力を増加させる。

(5)本論の例題で用いた比較的長尺の杭の場合には、杭端の拡底がイ ンピーダンスや基礎入力動に与える影響は小さい。

(6)パイルド・ラフト基礎の $1.5 \mathrm{~m}$ 程度のラフト部の拡大によるインピ 一ダンス・基䃈入力動一の影響は小さい。

(7)パイルド・ラフト基碤のインピーダンスは、水平成分では、杭基 礎や直接基礎と良く対応寸る。一方、上下成分と回転成分は低振 動数域で杭基礎とほぼ一致する。

(8)根入れを有する杭基礎の場合、基礎底面の埋土がインピーダンス と基礎入力動に与える影響はあまり顕著ではない。

(9)根入れを有する杭基礎のインピーダンスは、水平成分では根入れ 基礎と良く対态し、上下成分と回転成分は杭基礎と良く対応して いる。基碗入力動は根入れ基礎と杭基礎の中間的な性質を示す。

これらの結果は、単独の基礎の特性を扱う際に有用な知見といえ る。特に、解析モデルの作成において、影響の大きい要因と小さい 要因を明らかにすることは非常に重要であり、本論の結果はその裏 付けを与える意味を持っている。 


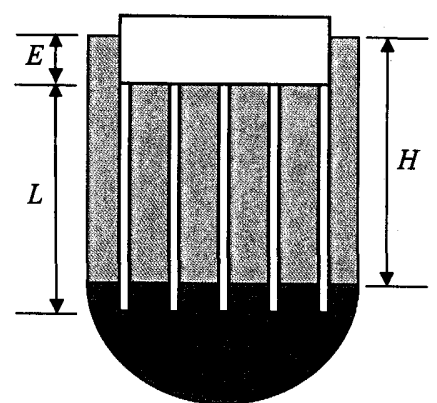

CASE1 根入れを有する杭基礎

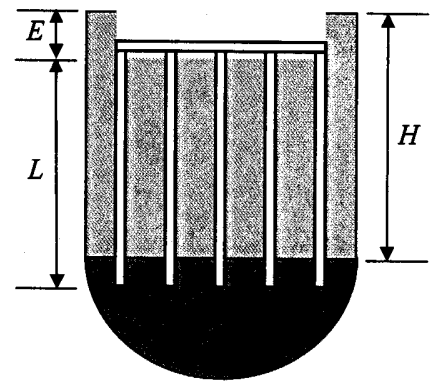

CASE3 杭基礎(根切り底にある)

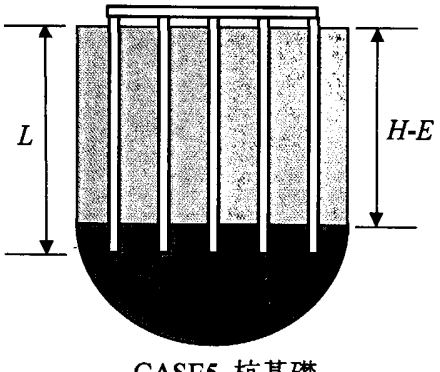

CASE5 杭基礎

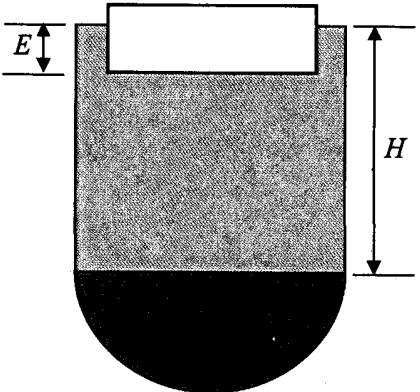

CASE2 根入れ基磷

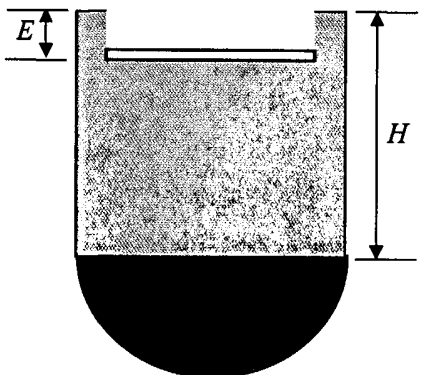

CASE4 直接基礎(根切り底にある)

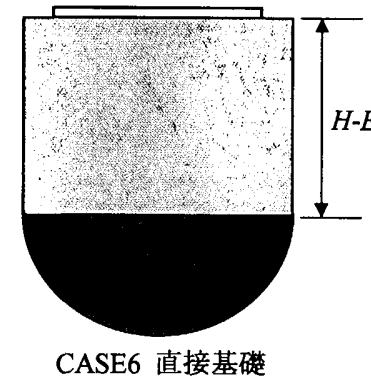

図 25 根入れを有する杭基礎と根入れ基礎、杭基礎との比較

本論をまとめるに当たって、名古屋大学大学院環境学研究科の飛 田潤助教授、小島宏章助手には有益な助言を頂いた。同大学院生の 酒井理恵子氏に協力を頂いた。また、日建設計の白瀬陽一氏、鹿島 建設の酒向裕司氏にはプログラム検証に当たって助言を頂いた。こ こに記して謝意を表する。

\section{参考文献}

1) Yoshida, K.: Fundamental Studies on Soil-Structure Interaction Problems, IRI Report 95-01, SHIMIZU CORPORATION, 1995

2) 長谷川正幸, 中井正一: 杭基磍のインピーダンス関数に基づいた群杭効率の 研究, 日本建築学会構造系論文報告集, No.417, pp. 133-145, 1990.11

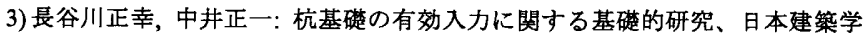
会構造系論文報告集, No. 422, pp. 105-115, 1991.4

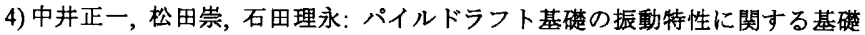
的検討、構造工学論文集, Vol. 4 7 B, pp.435-442, 2001.3

5) 喜多村英司, 宮本裕司, 三浦堅治, 增田潔: 埋め込みを有する群杭基碤の地震 忘答性状に関する研究，日本建築学会構造系論文集, No.492, pp.53-60, 1997.2

6)飯場正紀: 振動台実験に基つく建築物・基礎の地震時挙動及び地盤の影響を 取り入れた地震応答評価法の構築, 名古屋大学博士論文, 2002

7) 高野真一郎, 安井譲: 埋め込みを有する群杭の動的応答解析, 第 9 回日本地 震工学シンポジウム, pp. 1195-1200, 1994

8) 文学章, 福和伸夫: 隣接建物の存在が直接基整の動的相互作用特性に与える 影響，日本建築学会構造系論文集，No. 600，pp.97-105, 2006.2

9)文学章, 福和伸夫: 直接基鿎の基喽形状と基䂣形式が動的相互作用効果に及

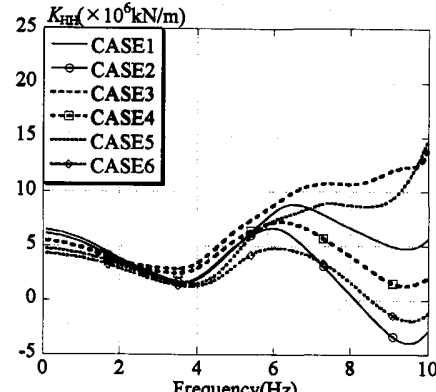

(a) 水平 (実部)

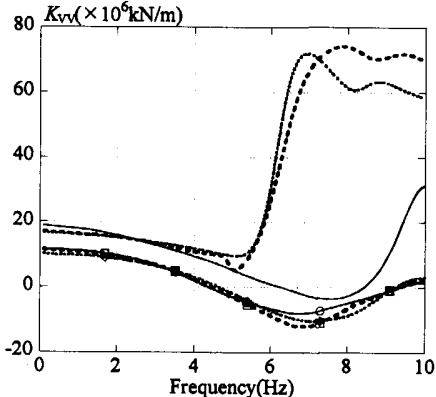

(c) 上下 (実部)

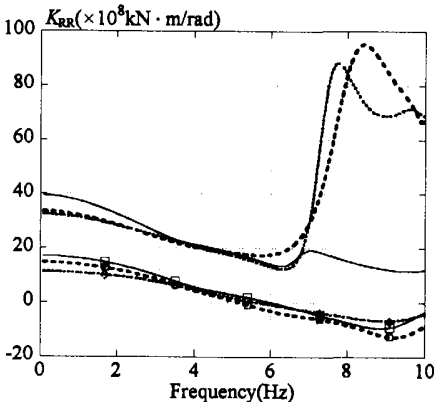

(e) 回転 (実部)

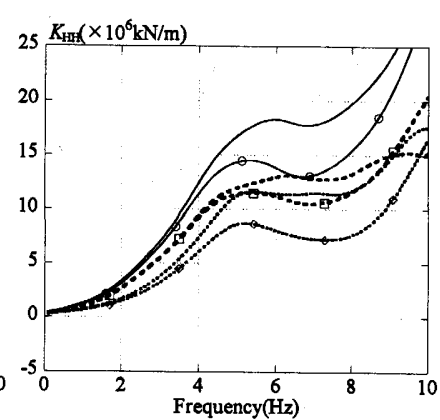

(b) 水平 (虚部)

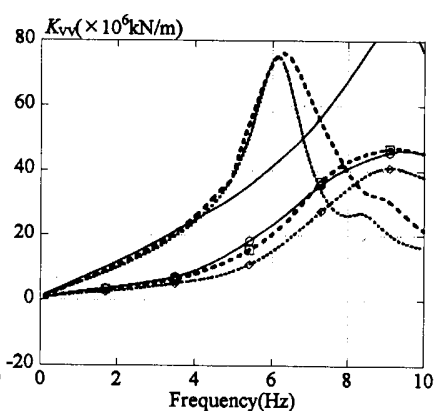

(d) 上下 (虚部) $100 \frac{K_{\mathrm{RR}}\left(\times 10^{8} \mathrm{kN} \cdot \mathrm{m} / \mathrm{rad}\right)}{2}$

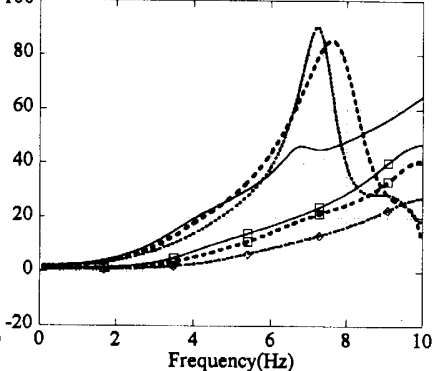

(f) 回転 (虚部)

図 26 根入れ基礎、杭基礎、根入れを有する杭基礎のインピ ーダンスの比較

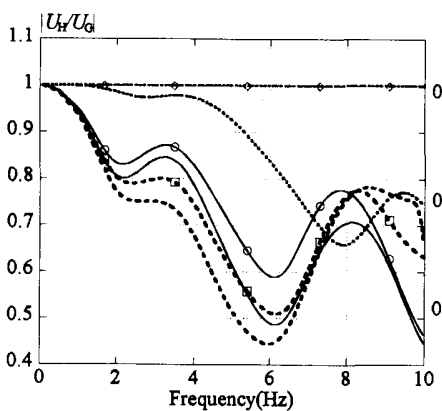

(a) 水平

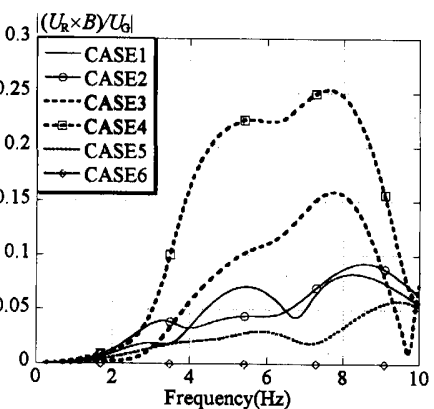

(b) 回転
図 27 根入れ基礎、杭基礎、根入れを有する杭基礎の基䃈入 力動の比較

ぼす影響、構造工学論文集, Vol. 52B, pp. 23-31, 2006.3

10) 日本建築学会 : 入門・建物と地盤との動的相互作用, 1996

11) J. Lysmer, R.M. Tabatabaie, F. Tajirian, S. Vahdani, F. Ostadan : SASSI - A System for Analysis of Soil-structure Interaction, UCB/GT/81-02, University of California, 1981

12) 増田潔，佐々木文夫：半無限層を考虑した薄層法による点加振解の検討, 日本建築学会大会学術講演梗概集, B-2,pp221-222, 1985

13) Kaynia, A. M. and Kausel, E.: Dynamic Behavior of Pile Groups, Proc. of Second International Conference on Numerical Method in Offshore Piling, pp.509-532, 1982 